\title{
PENGARUH PERMAINAN SAINS TERHADAP KEMAMPUAN BERPIKIR LOGIS ANAK
}

\author{
ALFIAN ASHSHIDIQI POPPYARIYANA \\ Universitas Muhammadiyah Sukabumi \\ E-mail: alfiantetepblie@gmail.com
}

Article received: 28 Desember 2019, Review process: 06 Januari 2020

Article published: 30 Maret 2020

\begin{abstract}
This study aims to determine The effect of science game on the logical thinking ability on the children in group B at TK Negeri Pembina Sragen. Research subjects were 45 children, consist of 22 children as experiment group and 23 children as control group. The experimental group was given the treatment of science game, while the control group was given lecture treatment. The instrument of data collection was using oral test and observation sheet. The data of this study was obtained from the results of the oral test and the observation sheet at the time before (pre-test) and after (post-test) learning. The data obtained was analyzed and tested by t-test statistic to see the difference between the experimental group and the control group. The results showed there is a very significant effect of science learning on logical thinking ability of children in group B at TK Negeri Pembina Sragen, with a significance value is 0.000 and an average difference of 6.99. These results show that science games can improve logical thingking ability in children.
\end{abstract}

Key words: science games, logical thinking ability, children.

\begin{abstract}
Abstrak
Penelitian ini bertujuan untuk mengetahui pengaruh permainan sains terhadap kemampuan berpikir logis anak kelompok B di TK Negeri Pembina Sragen, dan. Penelitian ini merupakan penelitian kuasi eksperimen, dengan sasaran anak kelompok B di TK Negeri Pembina Sragen. Subjek penelitian sebanyak 45 anak, terdiri atas 22 anak sebagai kelompok eksperimen dan 23 anak sebagai kelompok kontrol. Kelompok eksperimen diberikan perlakuan permainan sains, sedangkan kelompok kontrol diberi perlakuan ceramah. Instrumen pengumpulan data adalah menggunakan tes lisan dan lembar observasi. Data penelitian ini diperoleh dari hasil tes lisan dan lembar observasi pada saat pretest posttest. Data yang diperoleh kemudian dianalisis dan diuji dengan statistik uji-t untuk melihat perbedaan antara kelompok eksperimen dengan kelompok kontrol. Hasil penelitian menunjukkan bahwa ada pengaruh yang sangat signifikan dari pembelajaran sains terhadap kemampuan berfikir logis anak pada kelompok B di TK Negeri Pembina Sragen. Nilai signifikansi sebesar 0,000 dengan perbedaan rerata sebesar 6,99. Hasil tersebut menunjukkan bahwa permainan sains dapat berpengaruh kemampuan berpikir logis anak.
\end{abstract}

Kata kunci: permainan sains, kemampuan berpikir logis, anak. 


\section{PENDAHULUAN}

Pendidikan merupakan suatu berkah dari Allah terhadap ciptaannya. Manusia adalah satu-satunya makluk yang diciptakan dengan keadaan yang paling sempurna dan juga dibekali pikiran oleh sang maha pencipta. Manusia adalah makhluk yang ditakdirkan untuk memperoleh pendidikan. Pendidikan merupakan modal dasar untuk menyiapkan insan yang berkualitas.

Menurut Undang-undang Nomor 20 Tahun 2003 tentang sistem pendidikan nasional menyatakan bahwa Pendidikan adalah usaha sadar dan terencana untuk mewujudkan suasana belajar dan proses pembelajaran agar peserta didik secara aktif berkembang potensi dirinya, kecerdasan, akhlak mulia, serta keterampilan yang diperlukan dirinya, masyarakat, bangsa dan Negara. Pendidikan Nasional berfungsi mengembangkan kemampuan dan membentuk watak serta peradaban bangsa yang bermartabat dalam rangka mencerdaskan bangsa, bertujuan untuk berkembangnya peserta didik agar menjadi manusia yang beriman dan bertakwa kepada tuhan Yang Maha Esa, berakhlak mulia, sehat, berilmu cakap, kreatif, mandiri, dan menjadi warga Negara yang demokratis serta bertanggung jawab.

Anak usia dini berada dalam usia emas (golden age) yaitu sebuah masa yang paling tepat untuk meletakkan dasar-dasar pertama dalam mengembangkan kemampuan kognitif, fisik motorik, sosial emosi, bahasa, nilai moral agama, serta seni. Pengembangan kemampuan ini membutuhkan kondisi serta stimulasi yang sesuai dengan kebutuhan anak agar pertumbuhan dan perkembangan anak dapat tercapai secara optimal. Kegagalan dalam berinvestasi pada pendidikan awal ini bisa mengakibatkan keterlambatan pertumbuhan dan menghambat perkembangannya.

Aspek perkembangan kognitif sangat diperlukan oleh anak dalam mengembangkan pengetahuannya tentang apa yang dilihat, dirasa, didengar, diraba, dan juga dicium melalui panca indra yang dimilikinya. Kognitif merupakan suatu proses berfikir, yaitu sebuah kemampuan individu untuk menghubungkan, menilai serta mempertimbangkan suatu peristiwa. Pengembangan kemampuan kognitif menjadi sangat berpengaruh bagi kehidupan anak selanjutnya, karena melalui proses berfikir anak akan lebih terarah hidupnya. 
Johnston \& Halocha (2010: 65) berpendapat bahwa perkembangan kognitif seseorang melibatkan pengembangan pengetahuan, pemahaman konseptual serta kognisi. Kognisi melibatkan sejumlah keterampilan yaitu ingatan atau memori, kemampuan untuk berpikir abstrak, berpikir logis, memecahkan masalah, dan memberikan alasan.

Berpikir merupakan proses yang dialektis artinya, selama kita berfikir maka pikiran kita dalam keadaan tanya jawab untuk dapat meletakkan hubungan pengetahuan kita. Bumen menjelaskan bahwa pemikiran logis adalah keterampilan untuk menunjukkan perilaku seperti menggunakan angka secara efektif, menghasilkan solusi ilmiah untuk masalah, mengidentifikasi hubungan antara konsep, mengklasifikasi, generalisasi, meng-ungkapkan dalam rumus matematika, perhitungan, hipotesis, pengujian dan penggambaran analog (Aksu \& Koruklu, 2015: 183). Pemikiran logis membutuhkan pemikiran terus-menerus untuk mencapai sebuah kesimpulan. Proses berpikir sekuensial terletak pada inti pemikiran logis. Proses ini memerlukan perolehan semua gagasan, fakta dan hasil dan menempatkannya dalam rantai.

Othman dkk (2015: 86) berpendapat bahwa kemampuan berpikir logis merupakan salah satu faktor penting yang menentukan kemampuan siswa untuk menganalisa, merencanakan dan memecahkan masalah dalam kehidupan. Berpikir tidak memiliki indeks perilaku. Oleh karena itu, sulit bagi kita untuk mengamatinya dalam tindakan. McGregor (2007: 7) berpendapat bahwa dalam berfikir kita hanya dapat benar-benar menyimpulkan jenis pemikiran apa yang mungkin terjadi dengan mendengarkan anak-anak berbicara (melalui tanggapan terhadap pertanyaan, konservasi di antara teman sebaya), mengamati tindakan mereka (melalui peninjauan tulisan mereka), mengamati bagaimana mereka melakukan tugas praktis atau menilai apa yang mereka hasilkan (sebuah karya seni, cerita atau laporan atau bahkan penemuan sederhana).

Sekolah TK Negeri Pembina Sragen secara umum pembelajaran sudah cukup baik, akan tetapi didalam mengembangkan kemampuan berfikir logis masih terlihat sedikit kurang. Hal ini dapat dilihat ketika saat kegiatan belajar mengajar metode belajar yang dipakai guru kurang bervariasi sehingga kemampuan yang dimiliki anak kurang optimal. Materi yang diajarkan kepada anak kurang menggali atau mengasah kemampuan yang dimilikinya, 
Misalnya guru hanya mengajarkan membaca, menulis, dan berhitung sehingga mengesampingkan proses memperoleh pengetahuannya, karena yang terpenting untuk anak itu adalah prosesnya mendapatkan pengetahuan baru bukan hasilnya. Media yang dipakai guru untuk memberikan materi kurang menarik untuk anak, hal ini terlihat ketika anak merasa mudah bosan dengan apa yang telah disampaikan oleh gurunya.

Metode permainan sains ini dipilih untuk mengembangkan kemampuan berpikir logis, hal ini membuat anak akan terlibat secara langsung dalam proses pembelajaran, sehingga anak akan merasa tertarik terhadap pembelajaran yang dilakukan dan akan bersemangat dalam mengikuti proses belajar mengajar. Rahchmawati \& Kurniati (2010: 59) berpendapat bahwa pembelajaran sains akan melatih mengembangkan kreatifitas, kemampuan berfikir logis, senang mengamati, meningkatkan rasa ingin tahu, ilmu pengetahuan, kekaguman pada alam, dan lebih mengenal tuhan. Melalui permainan sains anak akan berkembang kemampuan berfikirnya. Anak anak akan terlibat secara langsung untuk mengamati, menyimpulkan dan mengklasifikasikan (Settlage \& Southerland, 2012: 55).

Kamudu dkk (2016: 262) berpendapat bahwa anak kecil membutuhkan pengalaman pertama sains untuk mengembangkan pengetahuan dan keterampilan mereka untuk mendapatkan pemahaman tentang fenomena di lingkungan mereka. Gopnik mengemukakan bahwa keingintahuan bawaan mereka membawa mereka untuk mengeksplorasi dan menikmati pengalaman di alam, dan secara bertahap, saat mereka tumbuh, mereka mengembangkan keterampilan proses ilmiah dan memulai gagasan tentang fenomena di dunia melalui pengalaman langsung bahwa anak-anak dapat terlibat dalam praktik dan bertindak sebagai ilmuwan intuitif (Kamudu dkk, 2016: 2).

Metode eksperimen menjadikan pendidik lebih kreatif serta inovatif didalam memberikan proses pembelajaran dan juga menjadi salah satu media yang dapat menarik perhatian serta minat anak dalam mengikuti kegiatan pembelajaran. Penelitian ini mengambil tema air, udara, dan api sebagai bahan permainan sains yang akan dilakukan anak TK Negeri Pembina Sragen.

Archer dalam penelitiannya menunjukkan bahwa sikap anak terhadap konsep sains dan ilmu pengetahuan pada dasarnya terbentuk selama tahun-tahun awal pendidikan mereka, dan 
menjadi sulit untuk berubah pada saat mereka mencapai usia remaja (Kermani \& Aldemir, 2015: 1505).

Menurut Eshach \& Fried (2005: 319) mengemukakan alasan mengapa anak usia dini perlu dikenalkan pembelajaran sains antara lain: (1) anak-anak secara alami menikmati, mengamati dan memikirkan alam, (2) mengekspos siswa untuk mengembangkan sikap positif terhadap sains, (3) pemaparan dini terhadap fenomena ilmiah menyebabkan pemahaman lebih baik tentang konsep ilmiah dipelajari kemudian secara formal, (4) penggunaan bahasa informasi ilmiah pada usia dini mempengaruhi perkembangan konsep ilmiah secara akhir, (5) anak-anak dapat memahami konsep dan alasan ilmiah secara ilmiah, dan (6) ilmu pengetahuan adalah sarana yang efisien untuk mengembangkan pemikiran ilmiah.

Mengingat betapa pentingnya mengembangkan kemampuan berpikir logis anak sejak usia dini, maka proses belajar anak seharusnya lewat bermain dan harus disesuaikan dengan tahapan perkembangan anak usia dini. Untuk itu penelitian ini diarahkan untuk mengembangkan kemampuan berpikir logis anak melalui permainan sains.

\section{METODOLOGI}

Penelitan ini menggunakan jenis penelitian Quasi Experiment. Desain yang digunakan adalah Non Equivalent Control Group Design, yaitu sebuah desain yang memberikan pretest terlebih dahulu sebelum memberikan perlakuan. Hasil perlakuan dapat diketahui lebih akurat, karena membandingkan antara keadaan sebelum diberi perlakuan dengan sesudah diberi perlakuan. Penelitian ini menggunakan 2 kelompok, yang terdiri dari kelompok eksperimen yang akan menggunakan permainan sains dalam pembelajaran dan kelompok kontrol yang menggunakan pembelajaran konvensional.

Tabel 1. Desain Eksperimen

\begin{tabular}{cccc}
\hline Kelompok & Pre Test & Treatment & Post Test \\
\hline Eksperimen & $\mathrm{O}_{1}$ & $\mathrm{X}$ & $\mathrm{O}_{2}$ \\
\hline Kontrol & $\mathrm{O}_{3}$ & - & $\mathrm{O}_{4}$ \\
\hline
\end{tabular}




\section{Keterangan}

$\mathrm{O}_{1} \quad$ : Observasi awal kelompok eksperimen sebelum perlakuan

$\mathrm{O}_{2} \quad$ : Observasi akhir kelompok eksperimen setelah perlakuan

$\mathrm{X}$ : Perlakuan menggunakan pembelajaran sains

$\mathrm{O}_{3} \quad$ : Observasi awal kelompok kontrol sebelum perlakuan

$\mathrm{O}_{4} \quad$ : Observasi akhir kelompok kontrol setelah perlakuan

Populasi dalam penelitian ini adalah seluruh anak kelas TK Negeri Pembina Sragen Jawa Tengah, yang terdiri dari 3 kelas. Sampel dalam penelitian ini ada 2 kelas kelompok B, yang terdiri dari 1 kelas kelompok eksperimen dan 1 kelompok kontrol. Setelah dilakukan pengacakan untuk menentukan kelompok eksperimen dan kelompok kontrol, maka diperoleh bahwa kelas B1 dijadikan kelompok eksperimen yang akan diberikan treatmen permainan sains, dan kelas B2 dijadikan kelompok kontrol yang akan dijadikan pembanding dan diberikan pembelajaran seperti biasanya.

Teknik pengumpulkan data yang digunakan penelitian ini ada beberapa cara yakni observasi, wawancara terstruktur, dan kajian dokumentasi. Observasi adalah pengamatan dan pencatatan dengan sistematik fenomen-fenomen yang diselidiki, dalam arti yang luas observasi tidak hanya terbatas pada pengamatan yang dilakukan baik secara langsung maupun tidak langsung. Wawancara terstruktur adalah wawancara yang sudah ada aturannya, dimana peneliti menggunakan pedoman wawancara yang telah tersusun secara sistematis dan lengkap untuk pengumpulan datanya. Metode dokumentasi dipakai untuk mengumpulkan data dari sumber-sumber dokumen yang mungkin mendukung atau bahkan berlawanan dengan hasil wawancara. Dokumentasi berbentuk tulisan, gambar, atau karya-karya monumental dari seseorang.

Validitas dan reliabilitas instrumen dalam penelitian ini menggunakan pendapat para ahli (judgment experts) didalam menguji validasi. Instrumen yang sudah dikonstruksi tentang aspek-aspek yang akan diukur dengan berlandaskan teori tertentu kemudian dikonsultasikan kepada para ahli sesuai dengan lingkup yang diteliti. Pengujian reliabilitas instrumen dalam penelitian ini dilakukan secara eksternal yaitu dengan test-retest.

Teknik analisis data bertujuan untuk mengolah data yang diperoleh dari penelitian. Teknik analisis data pada penelitian ini menggunakan analisis statistik deskriptif dan analisis 
statistik inferensial. Uji normalitas ini digunakan untuk mengetahui data pada kelas eksperimen dan kelas kontrol berasal dari populasi yang berdistribusi normal atau tidak. Uji normalitas dalam penelitian ini menggunakan uji Shapiro Wilk. Menurut Triton (2006: 79) data yang dikatakan normal apabila probabilitas atau signifikasi > 0,05. Uji homogenitas digunakan untuk mengetahui sampel yang digunakan apakah berasal dari populasi yang homogen atau tidak. Uji Homogenitas dianalisis menggunakan Test of Homogeneity of Varians dengan Levene Statistics didalam program analisis SPSS 16.00. Triton (2006: 87) berpendapat bahwa data homogen apabila probabilitas (Sig.) $>0,05$ dan apabila probalitas (Sig.) $<0,05$ maka data tidak homogen.

Uji Hipotesis dalam penelitian ini menggunakan data pretest dan posttest kemampuan berfikir logis anak. Uji hipotesis yang dipakai adalah Independent Sample T-Test dengan fasilitas Program SPSS 20 for Windows. $\mathrm{H}_{\mathrm{o}}$ diterima bila besarnya Sig. (2-tailed) atau p lebih dari taraf kesalahan $(\alpha)$ 0,05 yang ditetapkan atau $\mathrm{p}>\alpha$, sedangkan $\mathrm{H}_{\mathrm{o}}$ ditolak apabila besarnya Sig. (2-tailed) atau p kurang dari taraf kesalahan $(\alpha) 0,05$ yang ditetapkan atau $p<\alpha$.

\section{HASIL DAN PEMBAHASAN}

\section{Data Pretest Kemampuan Berpikir Logis}

Data kemampuan berpikir logis anak diperoleh dari tes lisan dan lembar observasi. Hasil pretest kemampuan berpikir logis merupakan statistik deskriptif kelompok eksperimen menunjukkan bahwa nilai rerata kemampuan berpikir logis anak adalah 66,95 dengan standar deviasi 5,04. Nilai terendah 59 dan nilai tertinggi 77. Sedangkan kelompok kontrol menunjukkan bahwa nilai rerata kemampuan berfikir logis anak adalah 67,26 dengan standart deviasi 3,46. Nilai terendah 61 dan nilai tertinggi 73. Lebih jelasnya dapat dilihat pada tabel 1 dibawah ini:

\section{Tabel 2. Statistik Deskriptif Data Pretest Kemampuan Berfikir Logis}

\begin{tabular}{|l|l|c|}
\hline \multirow{2}{*}{ Statistik } & \multicolumn{2}{|c|}{ Variabel } \\
\cline { 2 - 3 } & \multicolumn{2}{|c|}{ Kemampuan Berfikir Logis } \\
\cline { 2 - 3 } & Kelas Eksperimen & Kelas Kontrol \\
\hline
\end{tabular}


AWLADY: Jurnal Pendidikan Anak

Homepage: www.syekhnurjati.ac.id/jurnal/index.php/awlady

Email : pgrasyekhnurjati@gmail.com

P-ISSN: 2541-4658

E-ISSN: 2528-7427

\begin{tabular}{|l|c|c|}
\hline Rerata & 66,95 & 67,26 \\
\hline Standar Deviasi & 5,04 & 3,46 \\
\hline Minimum & 59 & 61 \\
\hline Maximum & 77 & 73 \\
\hline
\end{tabular}

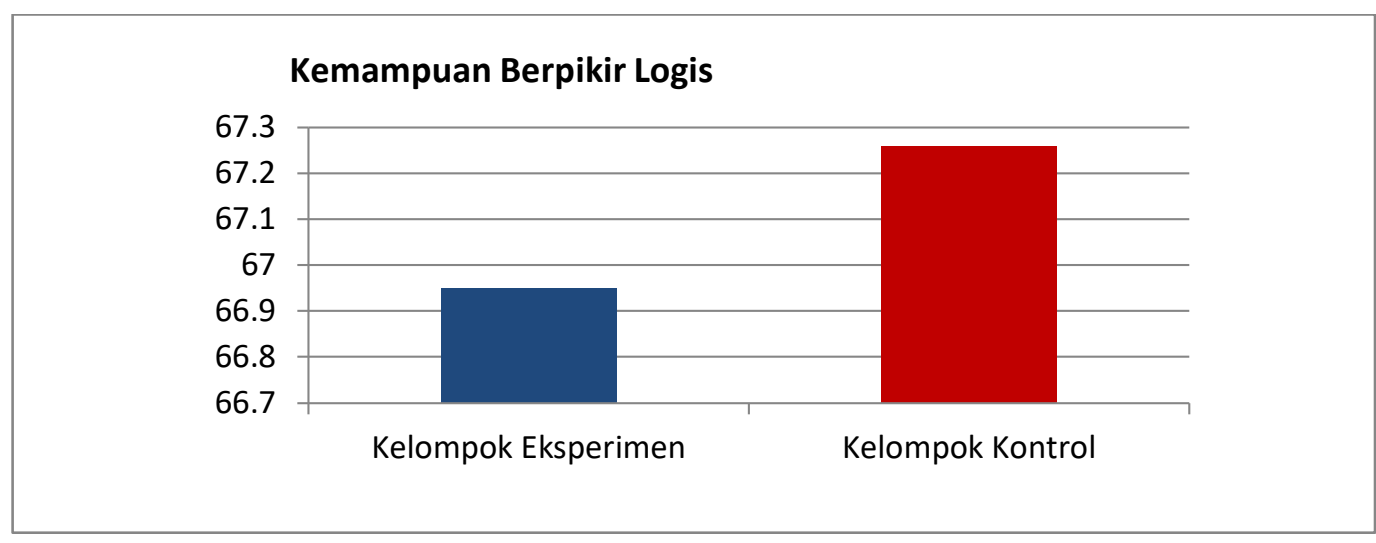

Gambar 1. Histogram Pretest Kemampuan Berpikir logis

\section{Data Posttest Kemampuan Berpikir Logis}

Data kemampuan berpikir logis anak diperoleh dari tes lisan dan lembar observasi. Hasil posttest kemampuan berpikir logis merupakan statistik deskriptif kelompok eksperimen menunjukkan bahwa nilai rerata kemampuan berpikir logis anak adalah 94,63 dengan standar deviasi 2,8. Nilai terendah 88 dan nilai tertinggi 100. Sedangkan kelompok kontrol menunjukkan bahwa nilai rerata kemampuan berfikir logis anak adalah 85,08 dengan standart deviasi 3,66. Nilai terendah 80 dan nilai tertinggi 93. Lebih jelasnya dapat dilihat pada tabel 1 dibawah ini:

\section{Tabel 3. Statistik Deskriptif Data Posttest Kemampuan Berfikir Logis}

\begin{tabular}{|l|c|c|}
\hline \multirow{2}{*}{ Statistik } & \multicolumn{2}{|c|}{ Variabel } \\
\cline { 2 - 3 } & \multicolumn{2}{|c|}{ Kemampuan Berfikir Logis } \\
\cline { 2 - 3 } & Kelas Eksperimen & Kelas Kontrol \\
\hline Rerata & 94,63 & 85,08 \\
\hline
\end{tabular}


AWLADY: Jurnal Pendidikan Anak

Homepage: www.syekhnurjati.ac.id/jurnal/index.php/awlady

Email : pgrasyekhnuriati@gmail.com

P-ISSN: 2541-4658

E-ISSN: 2528-7427

\begin{tabular}{|l|c|c|}
\hline Standar Deviasi & 2,8 & 3,66 \\
\hline Minimum & 88 & 80 \\
\hline Maximum & 100 & 93 \\
\hline
\end{tabular}

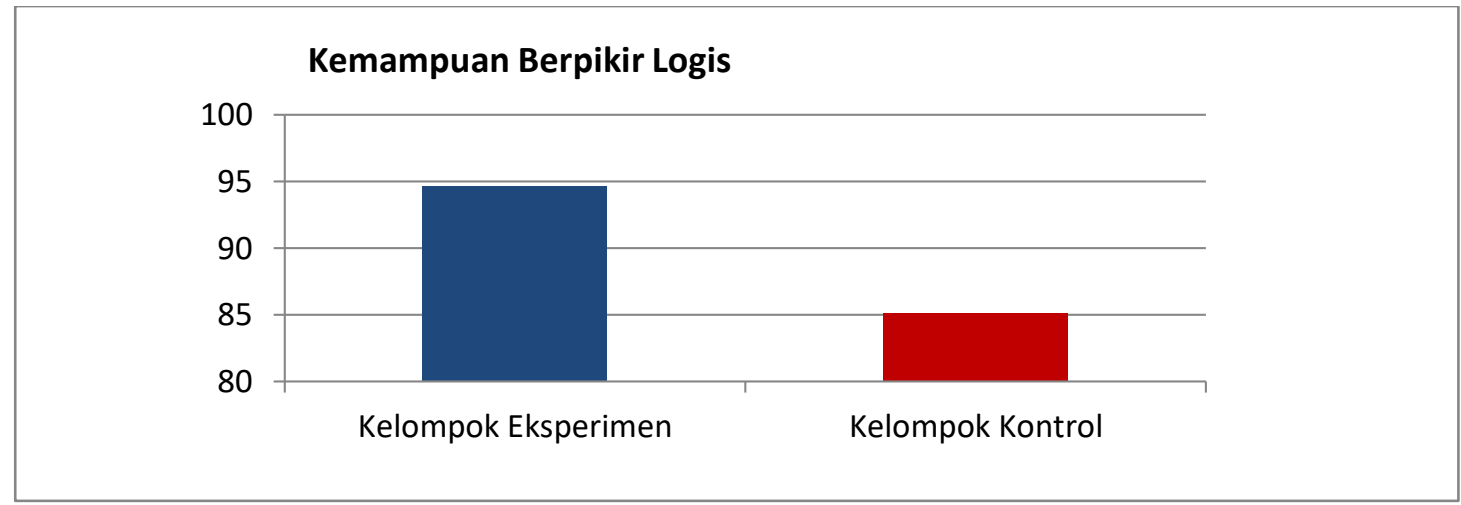

\section{Gambar 2. Histogram Posttest Kemampuan Berpikir logis}

\section{Uji Normalitas}

Uji normalitas dilakukan untuk mengetahui apakah data pada kelas eksperimen dan kelas kontrol berasal dari papulasi yang berdistribusi normal ataukah tidak. Teknik yang digunakan dalam uji normalitas ini adalah menggunakan uji Shapiro Wilk. Uji ini dilakukan dengan menggunakan program SPSS for Windows versi 16.0. dasar pengambilan keputusan untuk menentukan normalitas data apabila nilai signifikansi $>0,05$. Berikut merupakan hasil uji normalitas:

Tabel 4. Output Test of Normality

\section{Shapiro-Wilk}

\begin{tabular}{|ll|r|r|r|}
\hline \multirow{2}{*}{} & Kelas & \multicolumn{3}{|c|}{ Shapiro-Wilk } \\
\cline { 3 - 5 } & Kelas B1 & \multicolumn{1}{|c|}{ Statistic } & \multicolumn{1}{c|}{ Df } & \multicolumn{1}{c|}{ Sig. } \\
\hline Hasil Pretest Kemampuan & Kelas B2 & .923 & 22 & .088 \\
Berpikir Logis & .939 & 23 & .171 \\
\hline
\end{tabular}

a. Lilliefors Significance Correction

*. This is a lower bound of the true significance. 
Tabel 5. Output Test of Normality

\section{Shapiro-Wilk}

\begin{tabular}{|ll|r|r|r|}
\hline \multirow{2}{*}{} & \multirow{2}{*}{ Kelas } & \multicolumn{3}{|c|}{ Shapiro-Wilk } \\
\cline { 3 - 5 } & Kelas B1 & \multicolumn{1}{c|}{ Df } & \multicolumn{1}{c|}{ Sig. } \\
\hline Hasil Posttest Kemampuan & Kelas B2 & .954 & 22 & .373 \\
Berpikir Logis & Kela & 23 & .264 \\
\hline
\end{tabular}

a. Lilliefors Significance Correction

*. This is a lower bound of the true significance.

\section{Pretest Kemampuan Berpikir Logis}

Berdasarkan tabel 3 dapat diperoleh hasil perhitungan Shapiro-Wilk sebagai berikut. Nilai signifikansi pretest kemampuan berpikir logis kelompok eksperimen adalah 0,088. Artinya nilai signifikansi 0,088 > 0,05, maka data tersebut berdistribusi normal. Sedangkan nilai signifikansi kemampuan berpikir logis kelompok kontrol adalah 0, 171. Artinya nilai signifikansi $0,171>0,05$, maka data tersebut berdistribusi normal.

\section{Posttest Kemampuan Berpikir Logis}

Berdasarkan tabel 4 dapat diperoleh hasil perhitungan Shapiro-Wilk sebagai berikut. Nilai signifikansi pretest kemampuan berpikir logis kelompok eksperimen adalah 0,373. Artinya nilai signifikansi $0,373>0,05$, maka data tersebut berdistribusi normal. Sedangkan nilai signifikansi kemampuan berpikir logis kelompok kontrol adalah 0, 264. Artinya nilai signifikansi 0, $264>0,05$, maka data tersebut berdistribusi normal.

\section{Uji Homogenitas}

Uji homogenitas digunakan untuk mengetahui sampel yang digunakan apakah berasal dari populasi yang homogen atau tidak. Uji homogenitas dalam penelitian ini dengan menggunakan Test of Homogenity of Varians menggunakan Levene Statistic Program SPSS 16.0 for Windows. Dasar pengambilan keputusan untuk menentukan data homogen apabila nilai signifikansi > 0,05. Berikut merupakan hasil uji homogenitas: 
AWLADY: Jurnal Pendidikan Anak

Homepage: www.syekhnurjati.ac.id/jurnal/index.php/awlady

Email : pgrasyekhnurjati@gmail.com

P-ISSN: 2541-4658

E-ISSN: 2528-7427

Tabel 6. Output Levene Statistics

Test of Homogeneity of Variances

Hasil Pretest Kemampuan Berpikir Logis

\begin{tabular}{|r|r|r|r|}
\hline \multicolumn{1}{|c|}{ Levene Statistic } & df1 & df2 & \multicolumn{1}{c|}{ Sig. } \\
\hline 3.230 & & 1 & \\
\hline
\end{tabular}

Tabel 7. Output Levene Statistics

Test of Homogeneity of Variances

Hasil Posttest Kemampuan Berpikir Logis

\begin{tabular}{|c|c|c|c|}
\hline Levene Statistic & df1 & $\mathrm{df} 2$ & Sig. \\
\hline 1.455 & 1 & 43 & .159 \\
\hline
\end{tabular}

\section{Pretest dan Posttest Kemampuan Berpikir Logis}

Berdasarkan tabel 9 dapat diperoleh hasil perhitungan Levene Statistic sebagai berikut. Nilai signifikansi pretest kemampuan berpikir logis adalah 0,084. Artinya nilai signifikansi 0,084 >0,05, maka data tersebut homogen. Sedangkan berdasarkan tabel 11 dapat diperoleh hasil perhitungan Levene Statistic sebagai berikut. Nilai signifikansi posttest kemampuan berpikir logis adalah 0,159. Artinya nilai signifikansi 0,159>0,05, maka data tersebut homogen.

\section{Uji Hipotesis Pertama}

Hipotesis pertama berbunyi: terdapat perbedaan kemampuan berpikir logis kelompok eksperimen pada data pretest dan posttest di TK Negeri Pembina Sragen. Uji hipotesis pertama dianalisis menggunakan uji t yaitu dengan paired sample t test. Uji hipotesis pertama bertujuan untuk mengetahui perbedaan kemampuan berpikir logis data pretest dan data posttest. 
Tabel 8. Output Paired Sample T-Test

Paired Samples Test

\begin{tabular}{|c|c|c|c|c|c|c|c|c|c|}
\hline & & \multicolumn{5}{|c|}{ Paired Differences } & \multirow[b]{3}{*}{$\mathrm{t}$} & \multirow[b]{3}{*}{ Df } & \multirow{3}{*}{$\begin{array}{l}\text { Sig. (2- } \\
\text { tailed) }\end{array}$} \\
\hline & & \multirow[b]{2}{*}{ Mean } & \multirow{2}{*}{$\begin{array}{c}\text { Std. } \\
\text { Deviation }\end{array}$} & \multirow{2}{*}{$\begin{array}{l}\text { Std. } \\
\text { Error } \\
\text { Mean }\end{array}$} & \multicolumn{2}{|c|}{$\begin{array}{l}\text { 95\% Confidence } \\
\text { Interval of the } \\
\text { Difference }\end{array}$} & & & \\
\hline & & & & & Lower & Upper & & & \\
\hline $\begin{array}{l}\text { Pair } \\
1\end{array}$ & $\begin{array}{l}\text { Pretest - } \\
\text { Posttest }\end{array}$ & $2.76818 \mathrm{E} 1$ & 4.64334 & .98996 & 29.74056 & 25.62308 & 27.962 & 21 & .000 \\
\hline
\end{tabular}

Berdasarkan tabel 7, diperoleh nilai signifikansi sebesar $0,000<0,05$ dan nilai t hitung sebesar $-27,962 \leq \mathrm{t}$ tabel 1,721. Hal ini berarti terdapat perbedaan kemampuan berpikir logis kelompok eksperimen pada data pretest dan posttest di TK Negeri Pembina Sragen.

\section{Uji Hipotesis Kedua}

Hipotesis kedua berbunyi: terdapat perbedaan kemampuan berpikir logis kelompok kontrol pada data pretest dan posttest di TK Negeri Pembina Sragen. Uji hipotesis pertama dianalisis menggunakan uji $\mathrm{t}$ yaitu dengan paired sample $t$ test. Uji hipotesis pertama bertujuan untuk mengetahui perbedaan kemampuan berpikir logis data pretest dan data posttest.

Tabel 9. Output Paired Sample T-Test

Paired Samples Test

\begin{tabular}{|c|c|c|c|c|c|c|c|c|}
\hline & \multicolumn{5}{|c|}{ Paired Differences } & \multirow[b]{3}{*}{$\mathrm{t}$} & \multirow[b]{3}{*}{ Df } & \multirow{3}{*}{$\begin{array}{l}\text { Sig. (2- } \\
\text { tailed) }\end{array}$} \\
\hline & \multirow[b]{2}{*}{ Mean } & \multirow{2}{*}{$\begin{array}{c}\text { Std. } \\
\text { Deviation }\end{array}$} & \multirow{2}{*}{$\begin{array}{l}\text { Std. } \\
\text { Error } \\
\text { Mean }\end{array}$} & \multicolumn{2}{|c|}{$\begin{array}{l}95 \% \text { Confidence } \\
\text { Interval of the } \\
\text { Difference }\end{array}$} & & & \\
\hline & & & & Lower & Upper & & & \\
\hline $\begin{array}{ll}\text { Pair } & \text { Pretest - } \\
1 & \text { Posttest }\end{array}$ & $-1.78261 \mathrm{E} 1$ & 2.12458 & .44301 & -18.74482 & -16.90735 & -40.239 & 22 & .000 \\
\hline
\end{tabular}

Berdasarkan tabel 8, diperoleh nilai signifikansi sebesar $0,000<0,05$ dan nilai t hitung sebesar $-40,293 \leq \mathrm{t}$ tabel 1,717. Hal ini berarti terdapat perbedaan kemampuan berpikir logis kelompok kontrol pada data pretest dan posttest di TK Negeri Pembina Sragen. 


\section{Uji Hipotesis Ketiga}

Hipotesis ketiga berbunyi: Ada pengaruh positif permainan sains terhadap kemampuan berpikir logis di TK Negeri Pembina Sragen. Uji hipotesis dianalisis menggunakan uji t yaitu dengan independent sample $t$ test. Uji hipotesis kelima bertujuan untuk mengetahui pengaruh positif permainan sains terhadap kemampuan berpikir logis.

\section{Tabel 10. Output independent Sample \\ T-Test}

Independent Samples Test

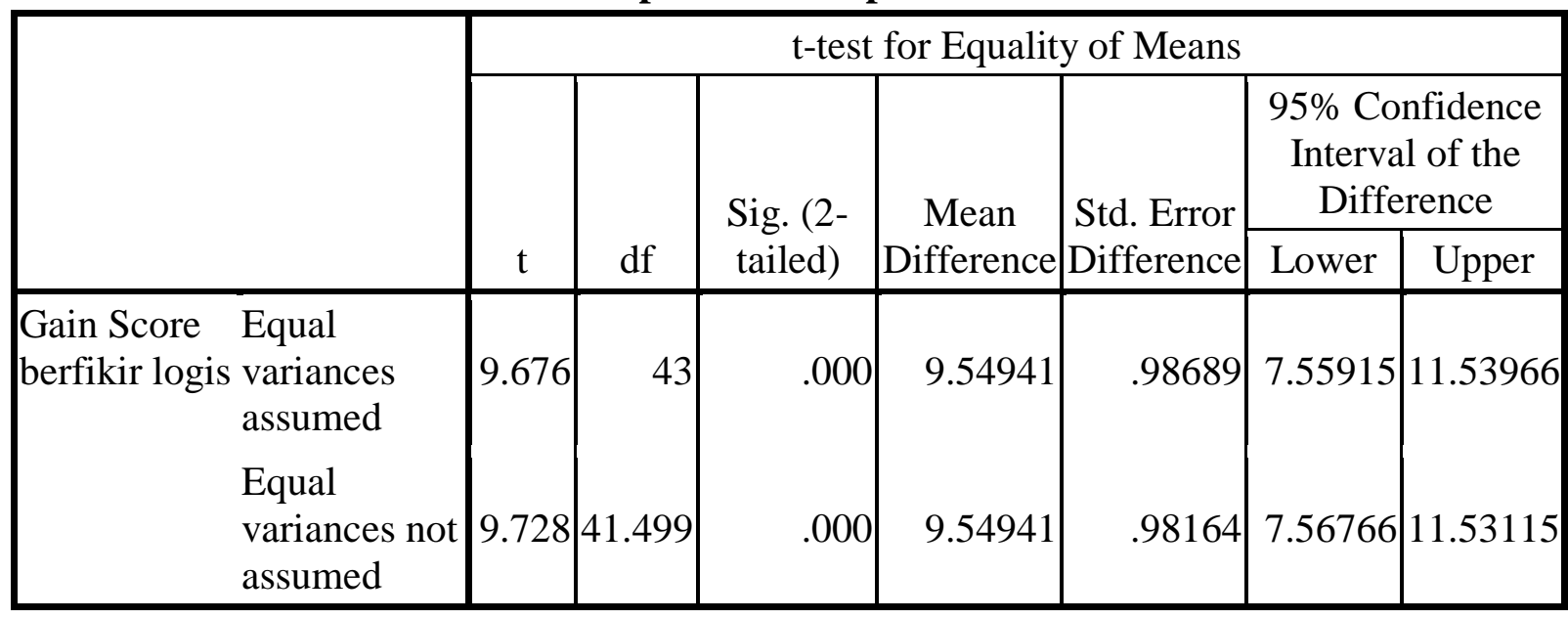

Berdasarkan tabel 9, diperoleh nilai signifikansi sebesar $0,000<0,05$. Hal ini berarti ada pengaruh positif yang sangat signifikan permainan sains terhadap kemampuan berfikir logis di TK Negeri Pembina Sragen.

Berdasarkan hasil observasi secara langsung yang dilakukan sebelum penelitian eksperimen, peneliti melihat kemampuan berpikir logis anak dalam mengenal konsep sederhana, mengenal perbedaan benda, mengenal sebab-akibat, mengemukakan ide, dan mengklasifikasikan benda dapat dikatakan masih rendah. Selain berpikir logis, keterampilan berbicara anak juga masih rendah, seperti jumlah kosakata, lafal atau ucapan anak yang cenderung kurang jelas, dan saat anak menyusun struktur kalimat ketika berbicara. Hal ini dikarenakan anak tidak distimulus sebagaimana mestinya, sehingga anak terlihat kurang aktif mengikuti proses pembelajaran. Selain itu metode pembelajaran yang digunakan oleh guru kurang bervariasi dan cenderung monoton, sehingga membuat anak cepat terlihat bosan serta kurang tertarik dengan yang diajarkan oleh guru. Berangkat dari permasalahan ini, peneliti 
berupaya memberikan metode permainan sains untuk meningkatkan kemampuan berpikir logis dan keterampilan berbicara anak.

Penelitian ini telah membuktikan bahwa melalui permainan sains dapat meningkatkan kemampuan berpikir logis anak. Hal ini ditujukkan bahwa terdapat pengaruh yang signifikan pada kelompok eksperimen yang diberikan perlakuan permainan sains, sedangkan kelompok kontrol yang diberikan materi ceramah juga meningkat akan tetapi tidak signifikan.

Pengaruh permainan sains terhadap kemampuan berpikir logis ini terbukti dari adanya peningkatan antara rerata saat skor pretest atau sebelum diberikan perlakuan dan skor posttest setelah diberikan perlakuan. Pada permainan sains ini anak diajarkan tentang konsep benda tenggelam dan terapung, konsep benda yang mudah dan sulit terbakar, serta konsep tekanan udara.

Dari semua permainan yang dilakukan, percobaan tentang konsep udara adalah yang paling anak sukai. Anak terlihat sangat antusias ketika diajak membuat roket dari balon, anak terlihat juga sangat menikmati permainan itu sehingga mereka bebas bereksplorasi. Hal ini sesuai dengan pendapat Gopnik bahwa keingintahuan bawaan mereka membawa mereka untuk mengeksplorasi dan menikmati pengalaman, dan secara bertahap, saat mereka tumbuh, mereka mengembangkan keterampilan proses ilmiah dan memulai gagasan tentang fenomena di dunia melalui pengalaman langsung bahwa anak-anak dapat terlibat dalam praktik dan bertindak sebagai ilmuwan intuitif (Kamudu dkk, 2016: 2).

Pembelajaran haruslah berpusat pada anak, bukan pada guru. Pembelajaran yang berpusat pada anak akan meningkatkan keaktifan serta memberikan kesempatan kepada anak untuk mengeksplorasi pengetahuan secara langsung melalui benda-benda konkret serta membentuk pengetahuan yang bermakna bagi anak. Permainan sains merupakan sarana yang tepat untuk mengenalkan hal-hal baru kepada anak, karena dalam permainan sains ini anak diajak untuk melihat, mengamati, dan mencoba sendiri permainan sains ini, setelah itu, anak menyampaikan tentang temuan apa yang mereka dapatkan dari permainan sains ini.

Berdasarkan hasil penelitian dan uraian diatas, maka dapat diketahuai bahwa melalui permainan sains memberikan dampak terhadap peningkatan kemampuan berpikir logis dan keterampilan berbicara anak. Kemampuan berpikir logis dan keterampilan berbicara anak 
mengalami peningkatan setelah diberikan permainan sains dalam belajarannya. Anak terlihat lebih aktif dalam proses pembelajaran untuk memperoleh pengetahuan secara langsung dengan benda konkret.

Melihat kelebihan serta kekurangan yang terjadi selama proses penelitian dapat disimpulkan bahwa permainan sains dapat berpengaruh terhadap kemampuan berpikir logis dan keterampilan berbicara anak kelompok B di TK Negeri Pembina Sragen.

\section{SIMPULAN}

Berdasarkan data yang dikumpulkan, analisis data dan pembahasan maka hasil penelitian ini dapat disimpulkan bahwa terdapat pengaruh yang sangat signifikan pada permainan sains terhadap kemampuan berpikir logis anak kelompok B di TK Negeri Pembina Sragen. Berdasarkan hasil penelitian diatas, maka disampaikan beberapa saran yakni pendidik diharapkan menjadikan model pembelajaran dengan menggunakan metode permainan sains sebagai salah satu alternatif dalam melaksanakan proses belajar mengajar untuk meningkatkan kemampuan bepikir logis anak. Diharapkan penelitian ini dapat digunakan sebagai referensi penelitian selanjutnya, sehingga dapat dikembangkan menjadi penelitian yang lebih baik, karena masih banyak aspek perkembangan yang dapat dikembangkan melalui permainan sains.

\section{DAFTAR PUSTAKA}

Eshach, H. \& Fried, M.N. (2005). Should science be taught in early childhood?. Journal of Science Education and Technology, 14, 315-336.

Gordon, K.A, et all. (2014). Early childhood education "becoming a professional". Los Angeles: SAGE Publications inc.

Grifenhagen, J.F, et. All. (2017). Talking the talk: Translating research to practice. Early Child Development and Care, 187, 509-526.

Hurlock, E.B. (1978). Perkembangan anak. Jakarta: Erlangga.

Johnston, J. \& Halocha, J. (2010). Early childhood and primary education. New York: Open University Press.

Kamudu, A. B., Naugah, J. \& Maulloo, A. K. (2017). Empowering teachers to teach science in early years in mauritius. Early Child Development and Care, Routledge, 187, 261273.

Kermani, H. \& Aldemir, J. (2015). Preparing Children for Success: Integrating Science, Math, and Technology in Early Childhood Classroom. Early Child Development and Care, 185, 1504-1527. 
McGregor, D. (2007). Developing thinking; developing learning. New York: Open University Press.

Othman, M., Zain, M. \& Nurzaid. (2015). Online collaboration for programming: Assessing students' cognitive abilities. Journal of Distance Education, 16, 84-97.

Pemerintah Indonesia. 2006. Undang-Undang Republik Indonesia Nomor 20 Tahun 2003 tentang sistem pendidikan nasional. Jakarta : Sekretariat Negara.

Rachmawati ,Y \& Kurniati, E. (2010). Strategi pengembangan kreativitas pada anak usia taman kanak-kanak. Jakarta: Kencana.

Santrock, J. W. (2007). Perkembangan anak. Jakarta: Erlangga.

Settlage, J. \& Southerland, S.A. (2012). Teaching science to every child: second edition. New York: Routledge.

Suyanto, S dkk. (2005). Dasar-dasar pendidikan anak usia dini. Yogyakarta: Hikayat.

Tarigan. (2008). Berbicara sebagai suatu ketrampilan berbahasa. Bandung: Angkasa. 